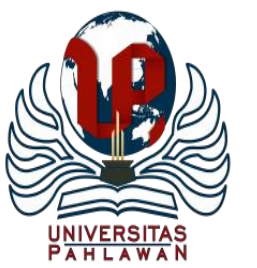

Jurnal Basicedu Volume 4 Nomor 4 Tahun 2020 Halm. 821 - 828

JURNAL BASICEDU

Research \& Learning in Elementary Education

https://jbasic.org/index.php/basicedu/index

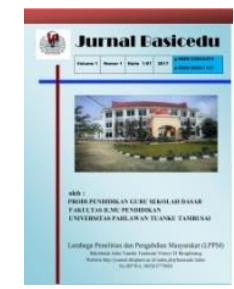

\title{
Peningkatan Hasil Belajar Matematika Melalui Pembelajaran Matematika Realistik di Sekolah Dasar
}

\author{
Feni herlina ${ }^{1}$, Taufina ${ }^{2}$ \\ Universitas Negeri Padang, Sumatera Barat, Indonesia ${ }^{1,2}$ \\ E-mail: feniherlina30@gmail.com ${ }^{1}$ taufina taufik@yahoo.co.id
}

\begin{abstract}
Abstrak
Tujuan penelitian ini adalah untuk mendeskripsikan peningkatan hasil belajar matematika dengan pendekatan Matematika Realistik di kelas VI SDN 18 V Koto Timur Padang Pariaman. Penelitian ini merupakan penelitian tindakan kelas yang terdiri dari II siklus. Penelitian ini dilaksanakan di SDN 18 V Koto Timur dengan subjek penelitian adalah siswa kelas VI yang berjumlah 10 orang. Hasil penilaian RPP siklus I diperoleh rata-rata 77\% dengan kriteria baik, siklus II 82\% dengan kriteria sangat baik. Penilaian aspek guru siklus I diperoleh rata-rata $76 \%$ dengan kriteria baik dan siklus II diperoleh $81 \%$ dengan kriteria sangat baik. Hasil belajar siswa pada siklus I diperoleh rata-rata 69\% dengan kriteria cukup dan siklus II $79 \%$ dengan kriteria baik. Pendekatan matematika realistik terbukti dapat meningkatkan kualitas pembelajaran matematika kelas VI SDN 18 V Koto Timur.
\end{abstract}

Kata kunci: hasil belajar, pembelajaran matematika, pendekatan matematika realistik

\begin{abstract}
The purpose of this study is to describe the improvement of mathematics learning outcomes with the Realistic Mathematics approach in class VI SDN $18 \mathrm{~V}$ Koto Timur Padang Pariaman. This research is a class action research consisting of II cycles. This research was conducted at SDN $18 \mathrm{~V}$ Koto Timur with 10 subjects as class VI students. The results of the first cycle of RPP assessment obtained an average of $77 \%$ with good criteria, the second cycle $82 \%$ with very good criteria. Assessment of the aspects of the first cycle of teachers obtained an average of $76 \%$ with good criteria and cycle II obtained $81 \%$ with very good criteria. Student learning outcomes in the first cycle obtained an average of $69 \%$ with sufficient criteria and $79 \%$ for the second cycle with good criteria. The realistic mathematics approach is proven to be able to improve the quality of mathematics learning in grade VI SDN 18 V Koto Timur.
\end{abstract}

Keywords: learning outcomes, mathematics learning, realistic mathematics approach

Copyright (c) 2020 Feni herlina, Taufina

$\triangle$ Corresponding author :

Address : Air Tawar Padang

Email :feniherlina30@gmail.com

ISSN 2580-3735 (Media Cetak)

Phone :-

ISSN 2580-1147 (Media Online)

DOI: $10.31004 /$ basicedu.v4i4.456 


\section{PENDAHULUAN}

Matematika merupakan mata pelajaran yang sulit dipahami sehingga siswa menjadi takut saat mendengar kata matematika(Prihandoko, 2006). Oleh karena itu, penguasaan terhadap matematika harus diperlukan dan konsep-konsep matematika harus dipahami dengan betul dan benar sejak dini. Suatu konsep disusun berdasarkan konsep-konsep sebelumnya dan akan menjadi dasar bagi konsepkonsep selanjutnya, sehingga pemahaman yang salah dari suatu konsep akan berakibat pada kesalahan pemahaman terhadap konsep-konsep selanjutnya.

Pembelajaran matematika hendaknya diterapkan dengan memberikan contoh yang dekat dengan kehidupan anak seperti diungkapkan oleh Suharta (Drs. I Ketut Dibia, 2013) mengatakan bahwa "bila anak belajar matematika terpisah dari pengalaman mereka sehari-hari maka anak akan cepat lupa dan tidak dapat mengaplikasikan matematika." Ini berarti bahwa pembelajaran matematika di kelas ditekankan pada keterkaitan antara konsep-konsep matematika dengan pengalaman anak sehari-hari. Berdasarkan pendapat itu maka pembelajaran hendaknya ditekankan pada keterkaitan konsep-konsep matematika dengan pengalaman siswa. Hal ini bertujuan agar pembelajaran lebih bermakna dan menyenangkan bagi siswa sehingga dapat memudahkan siswa dalam memahami konsep matematika, serta dapat menerapkan dalam kehidupan sehari-hari.

Kenyataan yang dilihat dilapangan berbeda dengan yang diharapkan dalam pembelajaran matematika. Berdasarkan pengamatan yang dilakukan oleh peneliti di kelas VI SD Negeri 18 $\mathrm{V}$ Koto Timur masalah yang peneliti temukan yaitu 1) RPP yang dibuat belum memakai pendekatan matematika realistik dan hanya memakai metode ceramah, tanya jawab, penugasan, 2) dalam penyampaian konsep matematika guru belum memberikan masalah konteks (nyata) yang dekat dengan siswa. 3) proses pembelajaran masih berpusat pada guru (teacher center), 4) guru hanya menjelaskan dan tidak menanamkan konsep materi yang dipelajari. Hal itu mengakibatkan siswa sulit memahami konsep sehingga siswa tidak dapat menyelesaikan soal dengan benar. Apabila diajukan pertanyaan tentang materi pelajaran, siswa juga tidak berani menjawab dan hanya diam. Siswa juga sering lupa dengan materi yang telah disampaikan dan bila diberikan soal siswa tidak dapat mengerjakan. Semua itu diakibatkan karena siswa kurang memahami konsep dari materi yang dipelajari. Kemudian karena metode pembelajaran yang konvensional maka siswa menjadi bosan dalam belajar.

Untuk mengatasi permasalahan yang dikemukakan diatas maka diperlukan suatu pendekatan yang tepat dalam pembelajaran sehingga berbagai permasalahan dalam belajar dapat diminimalisir. Taufina dan Muhammadi (Taufina dan Muhammadi, 2011) mengatakan bahwa pendekatan pembelajaran dapat diartikan sebagai titik tolak atau sudut pandang kita terhadap proses pembelajaran, yang merujuk pada pandangan tentang terjadinya suatu proses yang sifatnya masih sangat umum, didalamnya mewadahi, menginspirasi, menguatkan, dan 
melatari metode pembelajaran dengan cakupan teoritis tertentu. Jadi dari pendapat ahli di atas dapat disimpulkan bahwa pendekatan itu adalah suatu bentuk manajemen kelas yang terletak pada keterampilan guru dalam menilai, menentukan sikap dan perbuatan yang dihadapinya dengan memberikan fasilitas untuk memecahkan masalah dalam kegiatan belajar mengajar agar tercipta lingkungan yang menyenangkan dalam proses pembelajaran.

Pendekatan realistik yang lebih dikenal dengan Realistic Mathematics Education (RME) pertama kali dikenalkan di Belanda pada tahun 1970 oleh Institut Freudenthal. Pembelajaran dengan menggunakan pendekatan matematika realistik menekankan akan pentingnya konteks nyata yang dikenal siswa dan proses konstruksi pengetahuan matematika oleh siswa sendiri.Salah satu pendekatan yang cocok mengatasi permasalahan itu adalah pembelajaran matematika menggunakan pendekatan matematika realistik, akan memberikan kesempatan kepada siswa untuk menemukan sendiri konsep-konsep matematika sehingga siswa mempunyai konsep pengertian yang kuat. Hal ini sesuai dengan pendapat yang dikemukakan oleh Gravemeijer (Sutarto, 2006) bahwa "siswa harus diberikan kesempatan untuk menemukan kembali konsep dan prinsip matematika di bawah bimbingan orang dewasa". Hal tersebut dapat dilakukan dengan mengupayakan berbagai kondisi dan situasi serta permasalahan-permasalahan yang realistik, sehingga pembelajaran bermakna dan membuat siswa tertarik untuk belajar matematika serta dapat meningkatkan hasil pembelajaran.
Pendekatan ini berorientasikan pada penalaran siswa yang bersifat realistik sesuai dengan tuntutan kurikulum Ktsp. Hal ini dipertegas oleh Sutarto (Sutarto, 2006) yang menjelaskan bahwa "Dalam Pendekatan Matematika Realistik dunia nyata (real world) digunakan sebagai titik awal untuk pengembangan ide dan konsep matematika, dimana dunia nyata itu merupakan suatu dunia nyata yang konkret, yang disampaikan kepada siswa melalui aplikasi matematika.

\section{METODE}

Penelitian ini dilaksanakan di SDN $18 \mathrm{~V}$ Koto Timur Padang Pariaman. Subjek penelitian ini dilakukan pada siswa kelas VI di SD Negeri 18 V Koto Timur Padang Pariaman yang berjumlah 10 orang. Dengan jumlah laki-laki 6 orang dan perempuan 4 orang. Penelitian ini dilaksanakan pada semester I tahun ajaran 2017/2018 yang dilaksanakan dalam 2 siklus. Penelitian ini dilakukan yang terdiri dari siklus I dengan $2 \mathrm{x}$ pertemuan dan siklus II dengan 1x pertemuan.

Jenis penelitian yang penulis gunakan dalam penelitian ini adalah Penelitian Tindakan Kelas (PTK) kolaboratif, yaitu guru dan peneliti bekerja sama. yang dikenal dengan adanya siklus pelaksanaan berupa pola perencanaan, pelaksanaan, observasi dan refleksi. Menurut Suharsimi (Arikunto, 2016) yaitu proses penelitian tindakan kelas merupakan daur ulang yang diawali dengan perencanaan penelitian, pelaksanaan tindakan, mengobservasi, dan mengevaluasi proses hasil tindakan, dan melakukan refleksi, dan seterusnya sampai perbaikan atau peningkatan 
yang diharapkan dapat tercapai. Selanjutnya Suaidin (Jamal, 2011) mengemukakan bahwa Penelitian tindakan kelas diartikan sebagai "suatu kajian yang bersifat reflektif oleh pelaku tindakan, yang dilakukan untuk meningkatkan kemantapan rasional dari tindakan-tindakan mereka dalam melaksanakan tugas, memperdalam pemahaman terhadap tindakan-tindakan yang dilakukan itu, serta memperbaiki kondisi dimana praktik-praktik pembelajaran tersebut dilakukan.

Sumber data penelitian ini adalah proses pembelajaran matematika di kelas VI SD Negeri 18 V Koto Timur Kabupaten Padang Pariaman, yang meliputi perencanaan pembelajaran, pelaksanaan pembelajaran, kegiatan evaluasi pembelajaran prilaku guru dan siswa selama proses pembelajaran. Data diperoleh dari subjek yang diteliti, yakni guru dan siswa kelas VI SD Negeri 18 V Koto Timur Kabupaten Padang
Pariaman yang berjumlah 10 orang yaitu 4 orang perempuan dan 6 orang laki-laki.

\section{HASIL DAN PEMBAHASAN}

Berdasarkan tabel 1 di bawah ini dapat dilihat perencanaan RPP mengalami peningkatan, pada siklus I pertemuan I penilaian RPP 75\%, pertemuan II penilaian RPP 79\%, dengan rata-rata siklus I 77\% .Pada siklus II meningkat menjadi $82 \%$.

Berdasarkan tabel 2, di bawah, pelaksanaan pembelajaran mengalami peningkatan. Kegiatan guru pada siklus I pertemuan I $75 \%$, pertemuan II $78 \%$, dengan perolehan rata-rata siklus I 76\%. Pada siklus II meningkat menjadi $87 \%$. Kegiatan siswa pada siklus I pertemuan I $72 \%$, pertemuan II $72 \%$, dengan perolehan rata-rata pada siklus I adalah $72 \%$. Pada siklus II meningkat menjadi $81 \%$.

Tabel 1 Persentase Penilaian RPP

\begin{tabular}{|l|c|c|c|c|}
\hline \multirow{2}{*}{ No } & \multirow{2}{*}{ Kegiatan } & \multicolumn{2}{|c|}{ Siklus I } & Siklus II \\
\cline { 3 - 5 } & & Pertemuan I & Pertemuan II & Pertemuan I \\
\hline 1 & Penilaian RPP & $75 \%$ & $79 \%$ & $82 \%$ \\
\hline
\end{tabular}

Tabel 2 Persentase Pelaksannan Pembelajaran

\begin{tabular}{|c|c|c|c|c|}
\hline \multirow{2}{*}{ No } & \multirow{2}{*}{ Kegiatan } & \multicolumn{2}{|c|}{ Siklus I } & Siklus II \\
\cline { 3 - 5 } & & Pertemuan I & Pertemuan II & Pertemuan I \\
\hline 1 & Kegiatan Guru & $75 \%$ & $78 \%$ & $87 \%$ \\
\hline 2 & Kegiatan Siswa & $72 \%$ & $72 \%$ & $81 \%$ \\
\hline
\end{tabular}


Dari hasil penelitian yang peneliti laksanakan dengan menggunakan pendekatan matematika realistik di kelas VI SDN 18 V Koto Timur terungkap bahwa guru membuat perencanaan yang dimulai dengan membuat rancangan pembelajaran dalam bentuk RPP. Penilaian RPP yang peneliti lakukan meliputi 7 aspek yaitu: 1) Kejelasan perumusan tujuan pembelajaran, 2) pemilihan materi ajar,3) pengorganisasian materi ajar, 4) pemilihan sumber /media pembelajaran, 5) menyusun langkahlangkah pembelajaran, 6) metode pembelajaran, 7) kelengkapan instrumen.

Pelaksanaan pembelajaran pada siklus I sesuai dengan apa yang telah direncanakan. Pelaksanaan yang peneliti lakukan terdiri dari 3 langkah yaitu kegiatan awal, kagiatan inti, kegiatan akhir. Pada kegiatan awal guru mempersiapkan segala sesuatu yang berhubungan dengan pembelajaran yang akan dilakukan, berdoa, appersepsi, dan menyampaikan tujuan pembelajaran. Pada kegiatan inti dilaksanakan berdasarkan langkah-langkah yang telah direncanakan sebelumnya. Pada kegiatan akhir siswa menyimpulkan pelajaran dan mengerjakan latihan (tes). Pada kegiatan inti langkah-langkah yang dilaksanakan sesuai dengan langkah pembelajaran matematika realistik yang mengacu pada karakteristik pendekatan matematika realistik yang dikemukakan Gravemeijer (Daitin, 2006) adalah sebagai berikut: “1) penggunaan konteks, 2) instrumen vertikal, 3) konstribusi siswa, 4) kegiatan interaktif, 5) keterkaitan topik.

Berdasarkan analisis data hasil pengamatan aktivitas guru dan siswa yaitu Menyempurnakan lagi dalam membuat rencana pelaksanaan pembelajaran (RPP), memotivasi siswa agar berani dalam bertanya dan menyampaikan pendapat, lebih membimbing siswa untuk dapat memahami masalah yang diberikan, membimbing siswa agar dapat merumuskan masalah pengurangan dan dapat membuat model sendiri dalam menyelesaikan masalah dengan cara memberikan media yang lebih menarik, serta memotivasi siswa untuk menanggapi hasil diskusi kelompok temannya.

Hasil belajar merupakan perwujudan nilai yang diperoleh siswa melalui proses pembelajaran. Penilaian yang peneliti lakukan pada pembelajaran ini meliputi tiga aspek yaitu kognitif, afektif dan psikomotor. Penilaian aspek kognitif pada siklus I pertemuan I diperoleh skor dengan rata-rata 73 dengan nilai tertinggi 100 dan nilai terendah 50 . Pada pertemuan ke II dengan rata-rata 62 dengan niali tertinggi 80 dan nilai terendah 40 .

Rata-rata penilaian afektif pada siklus I adalah 69\% dengan kategori cukup. Pada siklus I ini ditemukan banyak siswa yang kurang memahami tentang pengurangan bilangan dengan cara bersusun panjang. Sedangkan rata-rata penilaian psikomotor pada siklus I adalah 67\% dengan kategori cukup. Pada siklus ini terlihat siswa tidak paham tentang pengurangan bilangan dengan cara bersususn panjang, oleh karena itu pada pertemuan selanjutnya guru lebih membimbing siswa dalam menemukan penyelesaian masalah.

Berdasarkan paparan data hasil pengamatan siklus I, maka direncanakan untuk melakukan perbaikan pada pembelajaran berikutnya pada 
siklus II. Perbaikan-perbaikan tindakan yang dilakukan pada siklus II diantaranya: 1) Memotivasi siswa agar aktif berdiskusi dalam kelompok, 2) Lebih membimbing siswa untuk paham memindahkan permasalahan ke bentuk matematika, 3) Memotivasi siswa untuk menanggapi hasil diskusi kelompok temannya, 4) Membimbing siswa menyimpulkan materi pelajaran, 5) Siswa mampu mengerjakan evaluasi yang diberikan guru dengan baik dan benar.

Pada siklus II, perencanaan pembelajaran pada siklus II tidak jauh berbeda dengan perencanaan pembelajaran siklus I. Perencanaan pembelajaran pada siklus II mencapai keberhasilan dengan sangat baik. Berdasarkan analisis data yang dilakukan oleh observer pada lembaran pengamatan RPP diketahui bahwa perolehan ratarata pada siklus II adalah $82 \%$ dengan kriteria sangat baik. Berdasarkan pemaparan data yang disajikan di atas, dapat disimpulkan bahwa perencanaan pembelajaran matematika dengan pendekatan matematika realistik di kelas VI SDN $18 \mathrm{~V}$ Koto Timur telah terlaksana dengan kriteria sangat baik pada siklus II.

Pembelajaran dipengaruhi oleh berbagai faktor seperti motivasi kematangan, hubungan siswa dengan guru, kemampuan verbal, tingkat kebebasan, rasa aman, dan keterampilan guru dalam berkomunikasi. Oleh karena itu guru harus melakukan perbaikan dalam pelaksanaan pembelajaran disamping perbaikan pada RPP. Guru harus dapat memberikan motivasi kepada siswa dalam pembelajaran. Peran guru dalam membelajarkan siswa sangat besar, upaya menimbulkan motivasi anak untuk belajar sangat berat

Tabel 3 Penilaian Terhadap Aktifitas Guru Dan Siswa

\begin{tabular}{|c|c|c|c|c|}
\hline \multirow{2}{*}{ No } & \multirow{2}{*}{ Kegiatan } & $\begin{array}{c}|c| \\
\text { Pertemuan } \\
\text { I }\end{array}$ & $\begin{array}{c}\text { Pertemua } \\
\text { n II }\end{array}$ & $\begin{array}{c}\text { Pertemuan } \\
\text { I }\end{array}$ \\
\hline & $\begin{array}{c}\text { Kegiatan } \\
\text { Guru }\end{array}$ & $75 \%$ & $78 \%$ & $87 \%$ \\
\hline \multirow{2}{*}{$\begin{array}{c}\text { Kegiatan } \\
\text { Siswa }\end{array}$} & $72 \%$ & $72 \%$ & $81 \%$ \\
\hline
\end{tabular}

Penilaian terhadap aktivitas guru pada siklus II yang dilaksanakan 1 kali pertemuan diperoleh persentase $87 \%$ dengan kriteria sangat baik (SB) dan pada aktivitas siswa $81 \%$ dengan kriteria sangat baik (SB). Dari perolehan persentase tersebut dapat dilihat peningkatan aktivitas guru dan siswa pada siklus II.

Berdasarkan data yang dipaparkan di atas diketahui bahwa pelaksanaan pembelajaran matematika dengan pendekatan matematika realistik di kelas VI SDN 18 V koto timur dari aktivitas guru dan siswa telah terlaksana dengan baik dan peneliti telah berhasil melaksanakan pembelajaran matematika dengan pendekatan matematika realistik.

Dari hasil analisis penelitian siklus II persentase hasil belajar dari aspek kognitif diperoleh persentase $85 \%$, dari aspek afektif diperoleh persentase $79 \%$ dan dari aspek psikomotor diperoleh persentase $72 \%$. Dari perolehan hasil belajar di atas diperoleh rata-rata hasil persentase hasil belajar pada siklus II adalah $79 \%$. Berdasarkan hasil pengamatan siklus II yang diperoleh maka pelaksanaan siklus II sudah baik dan guru sudah berhasil dalam usaha peningkatan hasil belajar matematika dengan pendekatan 
matermatika realistik di kelas VI SDN 18 Kecamatan V Koto Timur Kabupaten Padang Pariaman.

Berdasarkan paparan data perbandingan hasil penelitian siklus I dan siklus II, dapat disimpulkan bahwa hasil belajar siswa dalam pembelajaran matematika dengan menggunakan pendekatan matematika realistik pada siklus II berjalan jauh lebih baik dari siklus I. Siswa yang sebelumnya belum mencapai KKM, pada siklus II mampu mencapai KKM dan bahkan beberapa siswa mampu melebihinya. Jadi, dapat dikatakan bahwa guru telah berhasil dalam meningkatkan hasil belajar siswa dalam pembelajaran matematika dengan menggunakan pendekatan matematika realistik, yang dilihat dari hasil penilaian yang telah dilakukan.

Berdasarkan hasil pengamatan siklus II yang diperoleh, maka hasil tindakan pada siklus II ini sudah mencapai target yang diinginkan dan peneliti sudah berhasil dalam usaha meningkatkan hasil belajar siswa dalam pembelajaran matematika dengan pendekatan matematika realistik di kelas VI SDN 18 V Koto Timur Padang Pariaman.

\section{KESIMPULAN}

Berdasarkan paparan data dan hasil penelitian serta pembahasan, maka peneliti dapat menarik beberapa kesimpulan, yaitu : (1) Perencanaan pembelajaran matematika dengan pendekatan matematika realistik di kelas VI SDN 18 V Koto Timur Padang Pariaman diawali dengan penyusunan perencanaan yang dituangkan dalam bentuk RPP yang disesuaikan dengan kurikulum
K13 dan silabus pembelajaran. Penilaian RPP memperoleh skor $77 \%$ pada siklus I meningkat menjadi $82 \%$ pada siklus II. (2) Dalam pelaksanaannya telah terlaksana sesuai dengan langkah-langkah yang terdapat dalam pendekatan matematika realistik dimana langkah-langkah pembelajarannya dilaksanakan dalam tiga kegiatan pembelajaran yaitu kegiatan awal, kegiatan inti dan kegiatan akhir. Pada kegiatan awal, secara umum langkah-langkah yang dilakukan adalah pengkondisian kelas, membuka skemata siswa yang berhubungan dengan materi yang akan dipelajari, menyampaikan tujuan pembelajaran. Dalam kegiatan inti langkah-langkah yang dilakukan adalah penggunaan konteks, instrumen vertikal, konstribusi siswa, keterkaitan topik, dan keterkaitan topik. Sedangkan pada kegiatan akhir secara umum langkah-langkah yang dilakukan adalah menyimpulkan pembelajaran, memberikan tes secara individu, dan menutup pembelajaran. (3) Penilaian pelaksanaan pembelajaran siklus I pada aspek guru $76 \%$ dan siswa $72 \%$ meningkat pada siklus II pada aspek guru $87 \%$ dan aspek siswa menjadi $81 \%$. Hasil belajar siswa pun juga meningkat, dimana dari nilai rata-rata kelas dari 69 dengan kategori cukup pada siklus I, meningkat pada siklus II dengan rata-rata 79 dengan kategori baik. Dengan demikian dapat disimpulkan bahwa penggunaan pendekatan matematika realistik dapat meningkatkan hasil belajar siswa dalam pembelajaran matematika dengan pendekatan matematika realistik di kelas VI SDN 18 V Koto Timur Padang Pariaman.

Berdasarkan hasil penelitian, pembahasan dan kesimpulan yang telah diperoleh dalam 
penelitian ini, maka peneliti mengajukan beberapa saran: (1) Bentuk pembelajaran matematika melalui pendekatan realistik layak dipertimbangkan oleh guru untuk menjadi pembelajaran alternatif yang dapat digunakan sebagai referensi dalam memilih pendekatan pembelajaran, 2) Bagi guru yang ingin menerapkan pembelajaran dengan menggunakan pendekatan realistik, disarankan memperhatikan hal-hal sebagai berikut: a. materi pembelajaran disesuaikan dengan konteks sehari-hari siswa, b. perlu lebih kreatif dalam merancang pembelajaran yang sesuai dengan situasi dunia nyata,c. perlu memberikan perhatian, bimbingan dan motivasi belajar secara sungguh-sungguh kepada siswa yang berkemampuan kurang dan pasif dalam kelompok, karena siswa yang demikian sering menggantungkan diri pada temannya, 3) Guru perlu menyiapkan sarana dan prasarana yang dikenali siswa, karena akan mempermudah siswa memahami masalah, 4) Bagi peneliti selanjutnya disarankan untuk melakukan kajian mendalam tentang penerapan pendekatan pembelajaran dengan pendekatan realistik pada materi lain dalam matematika, 5) Kepada kepala Sekolah Dasar dan pejabat terkait kiranya dapat memberikan perhatian kepada guru terutama dalam meningkatkan hasil belajar dalam proses pembelajaran.

\section{DAFTAR PUSTAKA}

Arikunto, S. (2016). Penelitian Tindakan Kelas. In Bumi Aksara. Jakarta.

Daitin, T. (2006). Pembelajaran Matematika Realistik. Banjarmasin: Tulip.
Drs. I Ketut Dibia, S. (2013). Pengaruh Pendekatan Matematika Realistik (Pmr) Terhadap Hasil Belajar Matematika Kelas V Sd Desa Penglatan Kecamatan Buleleng. MIMBAR PGSD Undiksha, 2(1). https://doi.org/10.23887/jjpgsd.v2i1.2436

Jamal, M. (2011). Penelitian Tindakan Kelas. Jakarta: Laksana.

Prihandoko, A. cahya. (2006). Memahami Konsep Matematika Secara Benar dan Menyajikannya dengan Menarik (Departemen Pendidikan Nasional, ed.). Jakarta.

Sutarto, H. (2006). Pendidikan Matematika Realistik. In Pendidikan Matematika Realistik. Banjarmasin: Tulip.

Taufina dan Muhammadi. (2011). Mozaik Pembelajaran Inovatif (Sukabina Press, ed.). Padang. 